DOI 10.18551/rjoas.2021-10.29

\title{
THE EFFECT OF USING DIFFERENT PLASTICIZERS ON THE PHYSICAL AND CHEMICAL CHARACTERISTICS OF EDIBLE FILMS MADE FROM GROUPER SKIN GELATIN
}

\author{
Suprayitno Eddy \\ Department of Fisheries Technology, Faculty of Fisheries and Marine Science, \\ University of Brawijaya, Indonesia \\ E-mail: eddysuprayitno@ub.ac.id
}

\begin{abstract}
Gelatin is a protein extracted from animal collagen tissues in animal skin, bones, ligaments, or connective tissue. Gelatin is highly digestible, so that it is potentially used as a raw material for making edible films. The edible film is a thin layer made for coating or placed on top or between edible food components or can be consumed. In producing edible films made from hydrocolloids, the quality of the films is often fragile, therefore requiring additives that act as plasticizers. A plasticizer is a liquid with a high boiling point that will give soft and flexible properties when mixed with a polymer. The polyol group, including glycerol, sorbitol, and polyethylene glycol (PEG), is commonly used as plasticizers for edible films. The main research results showed that different plasticizers had a significant effect on the physical characteristics of edible films, namely the water vapor transmission rate, but had no significant effect on the tensile strength, thickness, elongation, and chemical characteristics of edible films, namely water content. The best edible film made from Grouper skin gelatin was obtained at a concentration of $1 \%$ glycerol plasticizer with physical and chemical characteristics, including the tensile strength of $12.07 \mathrm{MPa}$, elongation of $67.33 \%$, the thickness of $0.11 \mathrm{~mm}$, water vapor transmission rate of $167.50 \mathrm{~g} / \mathrm{m}^{2} /$ day, and water content of $13.22 \%$. The amino acid profile analysis results showed that the highest amino acid content of the edible film was glycine at $185,559.12 \mathrm{mg} / \mathrm{kg}$. In comparison, the lowest amino acid was L-Tyrosine at $2,893.97 \mathrm{mg} / \mathrm{kg}$.
\end{abstract}

\section{KEY WORDS}

Gelatin, edible film, glycerol, sorbitol, polyethylene glycol (PEG).

Optimal utilization of waste with low cost can create additional income, reduce fishery waste and increase the selling value of waste. One alternative that can be taken is to make gelatin from fish skin, one of which is Grouper skin. Fish skin contains collagen that produces gelatin when hydrolyzed (Ismail and Suprayitno, 2019).Gelatin is a protein extracted from animal collagen tissue in animal skin, bones, ligaments, or connective tissue. The addition of gelatin is highly important in diversifying food ingredients because of its high nutritional value, especially protein content, and low amino acids and fat content (Pantow et al., 2016). Gelatin functions as a stabilizer, thickener, emulsifier, gelling agent, edible coating, microencapsulation, foaming agent, and film former (Atma, 2016).

Gelatin is highly digestible, so that it is potentially used as a raw material for making edible films. Edible films can be made from three different types of constituent materials, namely hydrocolloids, lipids, and composites of both. The edible film is a thin layer made for coating or placed on top or between edible food components or can be consumed. In food products, edible films inhibit the transfer of water vapor and gas exchange, prevent loss of aroma and transfer of fat, improve physical characteristics, as a carrier for additives, and are environmentally friendly. The edible film is biodegradable packaging that is environmentally friendly and easy to decompose (Miwada et al., 2015). The manufacture of edible films usesnot only the main constituent materials but also plasticizers.

In producing edible films made from hydrocolloids, the quality of the films is often fragile, therefore requiring additives that act as plasticizers to increase the plastic properties when the films are pulled (Mulyadiet al., 2016). A plasticizer is a liquid with a high boiling 
point that will give soft and flexible properties when mixed with polymer (Arini et al., 2017). Appropriate types and concentrations of plasticizers will produce good film properties. The polyol group, including glycerol, sorbitol, and polyethylene glycol (PEG), is commonly used as plasticizers for edible films. This research was intended to develop gelatin from Grouper skin as a raw material for making edible films with different plasticizers to make it easier for people to apply it to packaging materials.

\section{MATERIALS AND METHODS OF RESEARCH}

The materials used in this research consisted of raw materials for the manufacture of gelatin, namely Grouper fish skin, citric acid (C6H807), distilled water,and water. Furthermore, the ingredients for making edible films were Grouper skin gelatin, glycerol, sorbitol, and polyethylene glycol (PEG).

This research employed an experimental method divided into two stages. The first stage was preliminary research aimed at finding the optimal concentration at each type of plasticizer, covering glycerol, sorbitol, and polyethylene glycol in the process of making edible films from Grouper skin gelatin. The second stage was the main research aimed at knowing the use of different plasticizers with optimal concentrations to produce edible films from Grouper skin gelatin with the best physical and chemical characteristics. Physical and chemical characteristics tests include thickness, tensile strength, elongation, water vapor transmission rate, water content, and amino acid profile.

The gelatin production began with preparing the raw material of Grouper fish skin and soaking it in warm water at $50^{\circ} \mathrm{C}$ for 30 minutes. The clean fish skin $(100 \mathrm{~g})$ was then weighed and cut into $1 \mathrm{~cm}^{2}$ size. Furthermore, the fish skin was soaked again using a $1 \%$ concentration of citric acid with a ratio of $1: 3(\mathrm{w} / \mathrm{v})$ for 24 hours. After finished, the fish skin was washed with running water until the $\mathrm{pH}$ was neutral, then extracted with a water bath at $60-70^{\circ} \mathrm{C}$ for 6 hours. The ratio between Grouper skin and distilled water was 1:3 (w/v). The next process was filtering the gelatin solution using a calico cloth. The filtered gelation solution was poured into a baking tray to be dried using an oven at a temperature of $60^{\circ} \mathrm{C}$ for 48 hours. The obtained gelatin was then mashed using a blender and stored in a desiccator for further analysis.

The first stage in the collagen production was to prepare the Grouper skin gelatin obtained in this research. Then, 5 grams of gelatin was weighed and then dissolved using $100 \mathrm{~mL}$ of distilled water until dissolved. The gelatin solution was heated on a hot plate at $60^{\circ}$ $\mathrm{C}$ for 15 minutes and stirred using a magnetic stirrer. Furthermore, variations in the concentration of plasticizers were added, namely $1 \%$ glycerol, $1.2 \%$ sorbitol, and $1 \%$ polyethylene glycol (PEG). All the ingredients mixed were stirred using a magnetic stirrer and reheated on a hot plate at a temperature of $60^{\circ} \mathrm{C}$ for 15 minutes until being homogenous. The mixture was then poured into an $18 \times 8 \mathrm{~cm}$ baking tray to be dried using an oven at a temperature of $65^{\circ} \mathrm{C}$ for 18 hours. The next stage was to conduct the peeling process to release the films. The films were stored in a desiccator and ready for testing.

Thickness was measured using a micrometer with an accuracy of $0.01 \mathrm{~mm}$. The measurement was carried out by placing the film between the jaws of the micrometer. The thickness measurement was made at 5 different points in each sample to get the average thickness of the edible film sample.

Tensile strength was measured using a Texture Analyzer. The thickness of the edible film specimen was measured using a micrometer and then affixed between the grips with an initial distance of $50 \mathrm{~mm} /$ minute. The tensile strength was calculated by dividing the maximum force $(F)$ applied to the film to tear $(\mathrm{N})$ per unit area of the film $(\mathrm{m})$. The tensile strength was calculated using the following formula:

$$
\text { Tensile Strength }\left(\mathrm{kgf} / \mathrm{cm}^{2}\right)=\frac{F}{N}
$$


The edible film samples were attached firmly to the ends of the two clamps. The measuring area was set to the appropriate weight, and the recorder was set to zero (default). The testof edible film samples wasdoneuntil they broke. Elongation is determined and calculated at the time the film breaks (expressed as a percentage). The formula for calculating elongation is as follows:

$$
\text { Elongation }(\%)=\frac{\text { Elongation of edible film }(\mathrm{cm})}{\text { The initial length of the edible film }(\mathrm{cm})} \times 100 \%
$$

The rate of water vapor transmission to the film was measured by the gravimetric method. The first step was to cut the film samples to be tested according to size affixed to a container containing silica gel. Before that, the silica gel was dried at $105^{\circ} \mathrm{C}$ for 2 hours. The measurement was taken every day for one week using the following formula:

$$
\text { WVTR }=\frac{G}{t \times A}
$$

Water content was analyzed using an oven. The porcelain cup was dried in the oven for 30 minutes, and then cooled in a desiccator for 15 minutes. Then, 5 grams of the sample was weighed in a cup and dried in an oven at $100^{\circ} \mathrm{C}$ under a pressure of not more than $10 \mathrm{mmHg}$ for 5 hours or until the weight was constant. The cup and its content were then cooled in a desiccator and weighed. The water content was calculated using the following formula:

$$
\text { Water Content }(\%)=\frac{B-C}{B-A} \times 100 \%
$$

Amino acid profile was analyzed using the UPLC method. 0.1 grams of the sample was weighed in a closed test tube, and then added with $5 \mathrm{~mL}$ of $\mathrm{HCl} 6 \mathrm{~N}$ and vortexed. The sample was flown with nitrogen gas. Furthermore, the tube containing the sample was put in an oven at $110^{\circ} \mathrm{C}$ for 22 hours. After cooling, the sample was transferred to a $50 \mathrm{~mL}$ volumetric flask and added with aquabidest (double-distilled water) to the border mark. The sample was filtered with a $0.45 \mu \mathrm{m}$ filter membrane. The amino acid concentration was calculated using the following formula:

$$
\begin{gathered}
\mu \mathrm{mol} A \mathrm{~A}=\frac{\text { peak area of sample } \times \text { standard concentration } \times \text { volume }}{\text { standard peak area }} \\
\% \mathrm{AA}=\frac{\mu \mathrm{mol} A A \times M r A A \times 100}{\mu \mathrm{g} \text { sample }}
\end{gathered}
$$

\section{RESULTS AND DISCUSSION}

Based on Figure 1, the tensile strength values with the additions of $1 \%$ glycerol plasticizer $(\mathrm{G}(1), 1.2 \%$ sorbitol plasticizer $(\mathrm{S}(1.2)$, and $1 \% \mathrm{PEG}$ plasticizer $(\mathrm{P}(1)$ were 12.07 $\mathrm{MPa}, 9.29 \mathrm{MPa}$, and $8.07 \mathrm{MPa}$ respectively. The addition of $1 \%$ glycerol plasticizer ( $G(1)$ resulted in the highest tensile strength,while the addition of $1 \%$ PEG plasticizer $(P(1)$ resulted inthe lowest tensile strength. The higher the concentration of plasticizer added, the lower the tensile strength. The addition of plasticizers caused plasticizer molecules to interact by forming hydrogen bonds in the chains between polymers, thereby reducing interactions between biopolymer molecules (Tanjung et al., 2020).

Figure 2 shows that the elongation values of the edible film with the additions of $1 \%$ glycerol plasticizer $(\mathrm{G}(1), 1.2 \%$ sorbitol plasticizer $(\mathrm{S}(1.2)$, and $1 \%$ PEG plasticizer $(\mathrm{P}(1)$ were $67.33 \pm 67,47 \%, 59.59 \pm 50.64 \%$, and $1.14 \pm 0.49 \%$ respectively. The addition of $1 \%$ glycerol plasticizer $(\mathrm{G}(1)$ resulted in the highest elongation value, while the addition of $1 \%$ PEG plasticizer $(P(1)$ resulted in the lowest elongation value. The highelongation value indicates that the edible film produced is not easily broken because of its ability to maintain the given 
load and tensile strength. The use of hydrocolloids can increase the breaking force and elongation because it produces a lubricating effect making edible film emulsion more elastic, flexible, and strong (Shinta et al., 2016).

Figure 3 shows that the thickness values of the edible film with the additions of $1 \%$ glycerol plasticizer (G(1), 1.2\% sorbitol plasticizer (S(1.2), and 1\% PEG plasticizer $(P(1)$ were $0.11 \pm 0.02 \mathrm{~mm}, 0.10 \pm 0.01 \mathrm{~mm}$, and $0.09 \pm 0.01 \mathrm{~mm}$ respectively. The addition of $1 \%$ glycerol plasticizer $(\mathrm{G}(1)$ resulted in the highest thickness value, while the addition of $1 \%$ PEG plasticizer $(P(1)$ resulted inthe lowest thickness value. The thickness of the edible film is influenced by the plasticizer used because plasticizers have hydrophilic properties that can increase the solubility and water vapor absorption ability of the edible film. Besides, plasticizer molecules play a role in destroying and restructuring intermolecular polymer tissues, causing a lot of space. Plasticizer molecules placed in the edible film matrix cavities will thicken the edible film (Suryadri et al., 2020).

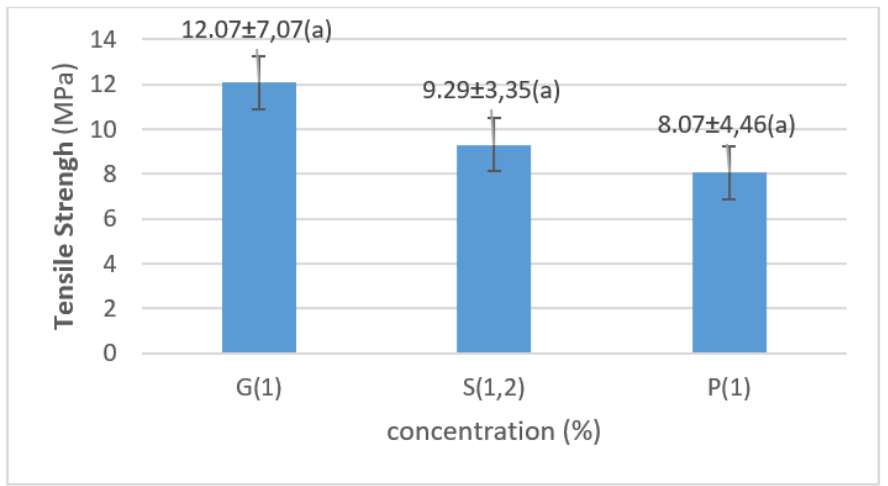

Figure 1 - Results of Tensile Strength

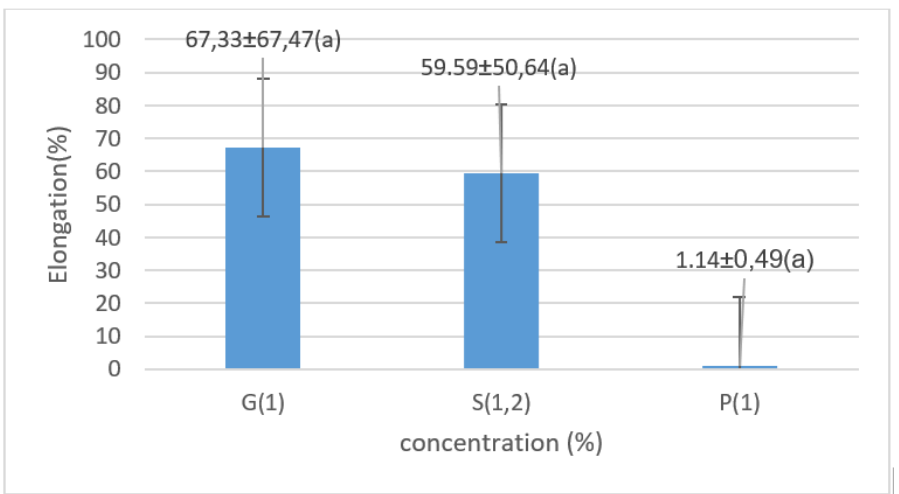

Figure 2 - Results of Elongation

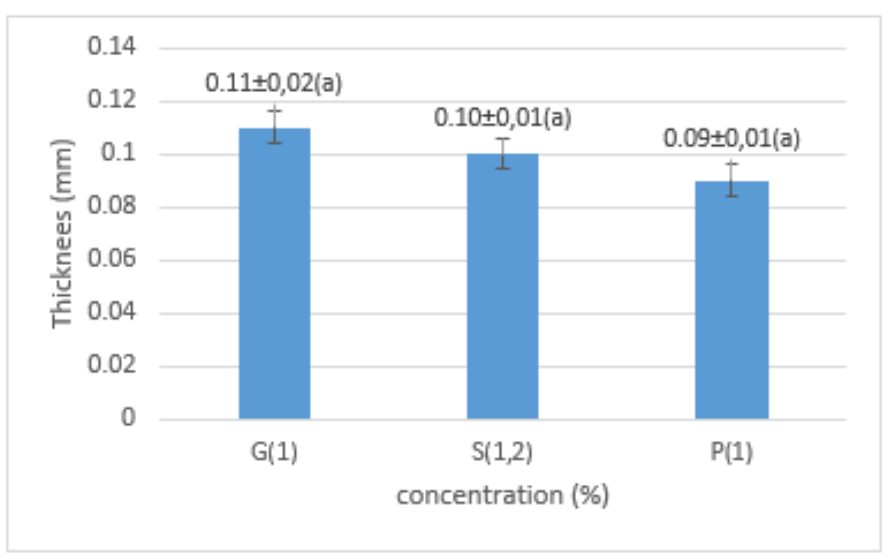

Figure 3 - Results of Thickness 


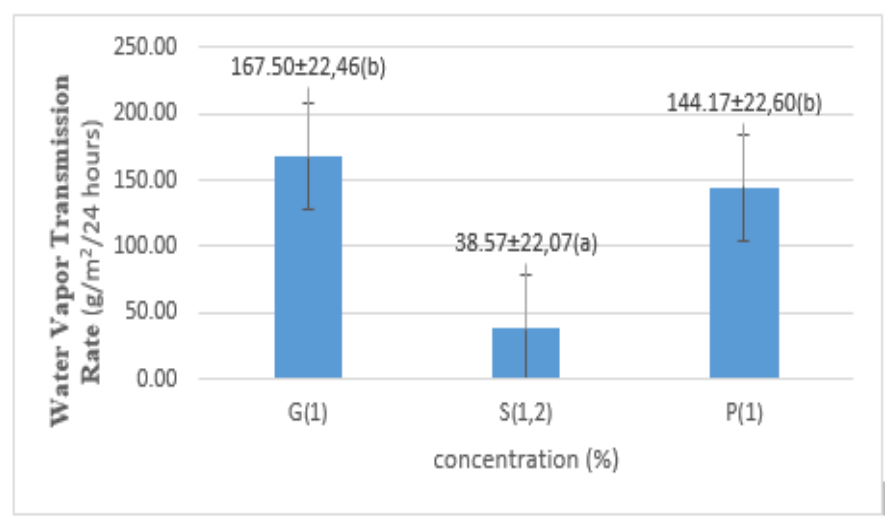

Figure 4 - Results of Water Vapor Transmission Rate

Figure 4 shows that the water vapor transmission rates of the edible film with the additions of $1 \%$ glycerol plasticizer $(\mathrm{G}(1), 1.2 \%$ sorbitol plasticizer $(\mathrm{S}(1.2)$, and $1 \% \mathrm{PEG}$ plasticizer $\left(P(1)\right.$ were $167.50 \pm 22.46 \mathrm{~g} / \mathrm{m}^{2} /$ day, $38.57 \pm 22.07 \mathrm{~g} / \mathrm{m}^{2} /$ day, and $144.17 \pm 22.60$ $\mathrm{g} / \mathrm{m}^{2} /$ day respectively. The addition of $1 \%$ glycerol plasticizer $(\mathrm{G}(1)$ resulted in the highest water vapor transmission rate, while the addition of $1.2 \%$ sorbitol plasticizer $(S(1.2)$ resulted in the lowest water vapor transmission rate. The Water Vapor Transmission Rate (WVTR) ofedible films are significantly influenced by the properties of the polymer used. The more hydrophilic and cationic a polymer, the higher the WVTR of the film (Ningrum et al., 2020).

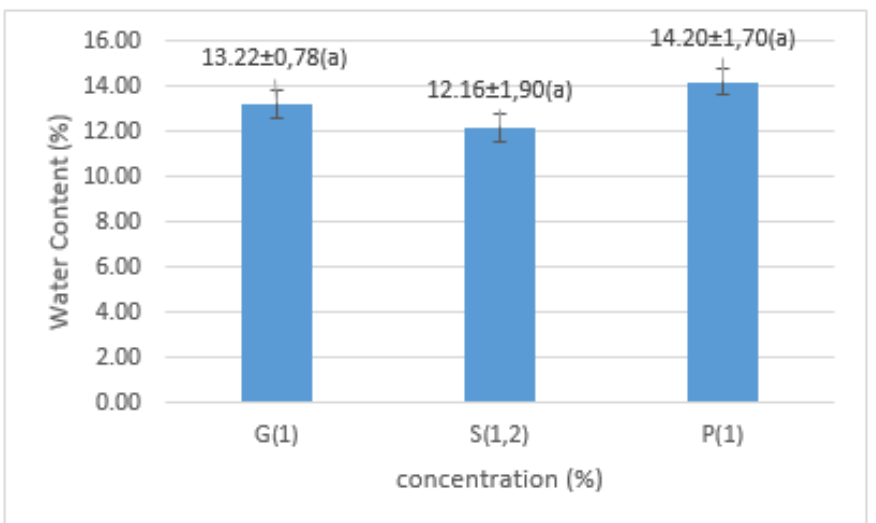

Figure 5 - Results of Water Content

Based on Figure 5, the water content values of the edible film with the additions of $1 \%$ glycerol plasticizer $(\mathrm{G}(1), 1.2 \%$ sorbitol plasticizer $(\mathrm{S}(1.2)$, and $1 \% \mathrm{PEG}$ plasticizer $(\mathrm{P}(1)$ were $13.22 \pm 0.78 \%, 12.16 \pm 1.90 \%$, and $14.20 \pm 1.70 \%$ respectively. The addition of $1 \%$ PEG plasticizer $(P(1)$ resulted in the highest water content value, while the addition of $1.2 \%$ sorbitol plasticizer $(S(1.2)$ resulted in the lowest water content value. The levels of water content in edible films are influenced by several factors, including basic ingredients and additives used in the film production process (Salimah et al., 2016).

Amino acid profile was analyzed to determine the amino acid composition contained in food ingredients. Amino acids can be found in foods containing protein. Amino acid content is influenced by the type, the observed organ, the age of harvest, and the physiological processes of the organism (Niccyet al., 2020).

As seen in the table 1, there were 15 amino acid types ranging from 4,200 mg/kg to $210,700 \mathrm{mg} / \mathrm{kg}$. The highest amino acid result was Glycine $(210,700 \mathrm{mg} / \mathrm{kg})$, and the lowest amino acid result was L-Tyrosine $(4,200 \mathrm{mg} / \mathrm{kg})$. Meanwhile, the result of L-Proline amino acid reached $102,300 \mathrm{mg} / \mathrm{kg}$. The main amino acid making up gelatin are glycine, proline, and hydroxyproline. According to Nasution et al. (2018), glycine and proline are the two main amino acids in gelatin, almost a quarter of the total amino acids in gelatin. Gelatin is made by partial hydrolysis of collagen. The alpha chain in collagen generally has a glycine-X-Y 
repeating sequence. Proline often occurs in the $X$ position. Therefore, these two amino acids are most abundant in gelatin. Grouper skin gelatin is then often used as a raw material in producing edible films.

Table 1 - The Analysis Results of the Gelatin Amino Acid Profile

\begin{tabular}{llll}
\hline No. & Parameter & Unit & Result \\
\hline 1 & L-Serine & $\mathrm{mg} / \mathrm{kg}$ & 26,300 \\
2 & L-Glutamic Acid & $\mathrm{mg} / \mathrm{kg}$ & 75,700 \\
3 & L-Phenylalanine & $\mathrm{mg} / \mathrm{kg}$ & 21,200 \\
4 & L-Isoleucine & $\mathrm{mg} / \mathrm{kg}$ & 7,900 \\
5 & L-Valine & $\mathrm{mg} / \mathrm{kg}$ & 16,700 \\
6 & L-Alanine & $\mathrm{mg} / \mathrm{kg}$ & 86,000 \\
7 & L-Arginine & $\mathrm{mg} / \mathrm{kg}$ & 80,600 \\
8 & Glycine & $\mathrm{mg} / \mathrm{kg}$ & 210,700 \\
9 & L-Lysine & $\mathrm{mg} / \mathrm{kg}$ & 25,800 \\
10 & L-Aspartic Acid & $\mathrm{mg} / \mathrm{kg}$ & 41,100 \\
11 & L-Leucine & $\mathrm{mg} / \mathrm{kg}$ & 19,200 \\
12 & L-Tyrosine & $\mathrm{mg} / \mathrm{kg}$ & 4,200 \\
13 & L-Proline & $\mathrm{mg} / \mathrm{kg}$ & 102,300 \\
14 & L-Threonine & $\mathrm{mg} / \mathrm{kg}$ & 23,700 \\
15 & L-Histidine & $\mathrm{mg} / \mathrm{kg}$ & 7,100 \\
\hline
\end{tabular}

Table 2 - The Results of the Amino Acid Profile of Edible Films

\begin{tabular}{llll}
\hline No. & Parameter & Unit & Result \\
\hline 1 & L-Serine & $\mathrm{mg} / \mathrm{kg}$ & $26,313.71$ \\
2 & L-Glutamic Acid & $\mathrm{mg} / \mathrm{kg}$ & $60,350.76$ \\
3 & L-Phenylalanine & $\mathrm{mg} / \mathrm{kg}$ & $21,897.08$ \\
4 & L-Isoleucine & $\mathrm{mg} / \mathrm{kg}$ & $9,635.56$ \\
5 & L-Valine & $\mathrm{mg} / \mathrm{kg}$ & $15,646.85$ \\
6 & L-Alanine & $\mathrm{mg} / \mathrm{kg}$ & $58,052.78$ \\
7 & L-Arginine & $\mathrm{mg} / \mathrm{kg}$ & $67,279.30$ \\
8 & Glycine & $\mathrm{mg} / \mathrm{kg}$ & $185,559.12$ \\
9 & L-Lysine & $\mathrm{mg} / \mathrm{kg}$ & $18,128.10$ \\
10 & L-Aspartic Acid & $\mathrm{mg} / \mathrm{kg}$ & $31,193.59$ \\
11 & L-Leucine & $\mathrm{mg} / \mathrm{kg}$ & $21,069.50$ \\
12 & L-Tyrosine & $\mathrm{mg} / \mathrm{kg}$ & $2,893.97$ \\
13 & L-Proline & $\mathrm{mg} / \mathrm{kg}$ & $84,613.99$ \\
14 & L-Threonine & $\mathrm{mg} / \mathrm{kg}$ & $15,861.99$ \\
15 & L-Histidine & $\mathrm{mg} / \mathrm{kg}$ & $5,904.01$ \\
\hline
\end{tabular}

As seen in the table of the amino acid profile of the edible films made from Grouper skin gelatin above, there were 15 amino acid types ranging from 2,893.97 $\mathrm{mg} / \mathrm{kg}$ to $185,559.12 \mathrm{mg} / \mathrm{kg}$. The highest amino acid result was Glycine $(185,559.12 \mathrm{mg} / \mathrm{kg})$, and the lowest amino acid result was L-Tyrosine $(2,893.97 \mathrm{mg} / \mathrm{kg})$. The high content of glycine and LProline in edible films is due to the high content of glycine and L-Proline owned by gelatin. The gelatin structure in fish skin is dominated by amino acids, including $14 \%$ hydroxyproline, $16 \%$ proline, and $26 \%$ glycine. It depends on the composition of the collagen in the raw material. The triple helix collagen structure is assembled from specific polypeptides with the glycine-X-Y position, where the $X$ position is filled with the proline amino acid, and the $Y$ position is filled with the hydroxyproline amino acid (Firdayanti and Suprayitno, 2019).Gelatin with a high glycine and proline amino acids will have a higher gel strength. Both amino acids also have an important role in the physical properties of gelatin. The glycine content in gelatin is highly important in binding water when applied to products (Utomo and Suprayitno, 2019).

\section{CONCLUSION}

The best edible film made from Grouper skin gelatin is obtained at a concentration of $1 \%$ glycerol plasticizer with physical and chemical characteristics, including the tensile strength of $12.07 \mathrm{MPa}$, elongation of $67.33 \%$, thickness of $0.11 \mathrm{~mm}$, water vapor transmission rate of $167.50 \mathrm{~g} / \mathrm{m}^{2} /$ day, and water content of $13.22 \%$. The results of amino acid profile analysis showed that the highest amino acid content of edible films was glycine at $185,559.12 \mathrm{mg} / \mathrm{kg}$, while the lowest amino acid was L-Tyrosine at 2,893.97 mg/kg. 


\section{REFERENCES}

1. Arini, D., M. Syahrul \& Kasman. (2017). Pembuatan and pengujian sifat mekanik plastik biodegradable berbasis tepung biji durian. Journal of Science and Technology, 6(3), 276283. ISSN: 2541-1969.

2. Atma, Y. (2016). Pemanfaatan limbah ikan sebagai sumber alternatif produksi gelatin and peptida bioaktif. Jurnal UMJ Seminar Nasional Sains and Teknologi. ISSN: 2460-8416.

3. Firdayanti, W., \& E. Suprayitno. (2019). Amino acid profile of gelatin extracted from the skin of starry triggerfish (Abalistes stellaris) and determination of its physical properties. International Journal of Scientific and Research Publications. 9(4), 774-778. ISSN: 22503153.

4. Ismail, S \& E. Suprayitno. (2019). The effect of variation of acetic acid concentration on characteristics of gelatin from milk fish skin (Chanoschanos). IOSR Journal of Agriculture and Veterinary Science(IOSR-JAVS), 12(5), 52-56. ISSN: 2319-2380.

5. Miwada, I. N. S., Simpen, I. N., Hartawan, M., Puger, A. W., \& Sriyani, N.P.L. (2015). Karakteristik gelatin dari kulit kaki ternak and potensinya sebagai edible film. Majalah IImiah Peternakan, 18(3), 109-113. ISSN: 0853-8999.

6. Mulyadi, A. F., M. H. Pulungan \& N. Qayyum. (2016). Pembuatan edible filmmaizena and uji aktifitas antibakteri (kajian konsentrasi gliserol and ekstrak daun beluntas (pluchea indica I.). JTMA, 5(3), 149-158. ISSN: 2549-3892.

7. Nasution, A. Y., Harmita, H., \& Harahap, Y. (2018). Karakterisasi gelatin hasil ekstraksi dari kulit ikan patin (Pangasius hypophthalmus) dengan proses asam and basa. Pharmaceutical Sciences \& Research, 5(3), 142 - 151. ISSN 2407-2354.

8. Niccy, S., Suhandana, M., \& Ilhamdy, A. F. (2020). Pengaruh perebusan terhadap karakteristik asam amino and logam berat pada daging keong bakau (Telescopium telescopium). Marinade, 3(1), 72-88. ISSN: 2654-4415.

9. Ningrum, R. S., D. Sondari., P. Amanda., B. A. Widyaningrum.,D. Burhani., F. Akbar \& Y.Sampora. (2020). Properties of edible film from modified sagostarch precipitated by butanol. JUSAMI, 21(4), 164-169. ISSN: 1411-1098.

10. Pantow, I. M., M. Sompie., A. D. Mirah., Linda \& M. Karisoh. (2016). Pengaruh perbedaan konsentrasi larutan asam asetat $(\mathrm{CH} 3 \mathrm{COOH})$ terhadap karakteristik gelatin kulit kaki ayam. Jurnal Zootek, 36(1), 23-32. ISSN: 0852-2626.

11. Salimah, T., W. F. Ma'ruf \& Romadhon. (2016). Pengaruh transglutaminase terhadap mutu edible film gelatin kulit ikan kakap putih (Lates calcalifer). Jurnal Pengolahan and Bioteknologi Hasil Perikanan, 5(1), 49-55. ISSN: 2442-4145.

12. Shinta, D., A. Supriadi and S.D. Lestari. 2016. Pemanfaatan air cucian surimi belut sawah (Monopterus albus) dalam pembuatan edible film. Jurnal FishtecH. 5(1): 85-93. ISSN: 2656-1913.

13. Suryadri,H., R. Andriani., M. G. Aditya D., \& Damris. (2020). Perbandingan penambahan CMC and sorbitol dengan penambahan gelatin and gliserol terhadap edible filmyang terbuat dari limbah cair tahu. Chempublish Journal, 5(2): 93-104. ISSN: 2503-4588.

14. Tanjung, M. R., Rostini, I, Ismail, M. R. \& Pratama, R. I.. (2020). Characterization of edible film from catfish (Pangasius sp.) surimi wastewater with the addition of sorbitol as a plasticizer.World News of Natural Sciences An International Scientific Journal. 28, 87102. ISSN: 2543-5426.

15. Utomo, A.M., \& E. Suprayitno. (2019). Analysis of the physicochemical properties of gelatin from mahi-mahi skin (Coryphaena hippurus). International Journal of Scientific and Research Publications,9(9), 832-836. ISSN: 2250-3153. 